\title{
Banking Sector Reforms and Money Market Performance: Evidence from Nigeria
}

\author{
Krokeme Okoyan *, Peter Ayunku ** \\ * Doctoral Student Banking \& Finance Niger Delta University, Wilberforce island Amassoma Bayelsa State. \\ ${ }^{* * *}$ Faculty of Management Science Niger Delta University, Wilberforce island Amassoma Bayelsa State \\ DOI: 10.29322/IJSRP.10.03.2020.p9932 \\ http://dx.doi.org/10.29322/IJSRP.10.03.2020.p9932
}

\begin{abstract}
This paper examined the relationship subsisting between banking sector reforms and money market. Annual data collected from the Central Bank of Nigeria (CBN) statistical bulletin spanning the period $2004-2018$ were analysed using the OLS model. The study adopted commercial paper as a proxy for money market performance, while banking reforms was proxied by credit to the private sector (CPS), broad money supply (M2) and total bank deposit (TD). Our findings revealed that an increase in the credit to the private sector (CPS) and total deposits (TD) will lead to a significant rise in the volume of commercial paper (CP) traded on the Nigerian Stock Exchange. While an increase in a rise in the total money supply in the economy will lead to a significant fall in the volume of commercial paper (CP) traded on the Nigerian Stock Exchange. To this tune, we recommend amongst others that the government continue to consolidate on existing reforms to improve deepening of the money market.
\end{abstract}

Index Terms- Banking sector, commercial paper, money market, money supply, credit

\section{INTRODUCTION}

$\mathrm{D}$ ue to the substantial improvement of the financial infrastructure, the restructuring of the regulatory and supervisory framework to tackle the issues of low capitalization and the organized funding of low-cost credit for the real sector are the main reasons why banking reforms are underway. Weakness in the banking system, marked by chronic illiquidity, insolvency, under-capitalization, high level of non-performing loans and weak corporate governance, among others, may cause a banking crisis (Adegbaju and Olokoyo, 2008). Monetary policy shocks can also weaken vulnerable banks'.

From 1956 to the present, various reforms have been carried out in the Nigerian banking industry; the essence of these reforms was to strengthen the banking system to meet current realities and changes in line with international best practices and to save depositor funds. This work would primarily concentrate on the CBN's July 6, 2004 banking sector reform, with a clear mandate to ensure stability and economic prosperity. In his words, Professor Charles Soludo, the then Governor of the Central Bank of Nigeria from June 2004 to June 2009, said the reforms were designed to create exchange rate and price stability, manage interest rates for stability and growth of macroeconomic coordination, follow vigorously the CBN's developmental functions, strengthen the payment system, diversify the financial sector while issuing regulatory reforms and policies to incorporate the financial system of Nigeria into a regional and global financial system.

He also stressed his intention to concentrate on the restructuring of the banking sector. The restructuring of the banking system was to be the first stage of reforms aimed at securing a diverse, strong and confident banking sector that will secure capital for depositors, play an active development role in the Nigerian economy and be effective and successful players in the regional and global financial system in Africa. The move was to help the banks become strong players for good health, long live and positive economic contributors. Depositors had been supposed to have sweet dreams after this reform. The universal banking system introduced in 1999 turned banks into one-stop shops offering a range of financial services, insurance, mortgage, stock broking, investment, banking, etc. Unfortunately, following the observation that the banks were jeopardizing the funds of shareholders and not concentrating on their core areas of competence, the central bank of Nigeria announced on 15 March 2010 the phasing out of universal banking, which lasted 18 months. All these reforms have taken place but many people still have doubts about the benefits, especially as it relates to bank results. Several other banks have gone down the lane after the Soludo's bank recapitalisation. Examples include Oceanic Bank, Intercontinental Bank, Afri Bank and others. The recent wage of downsizing banks and cutting allowances for staff had been a crucial issue for the Nigerian economy.

In a simple reasoning, the banks are still not performing satisfactorily despite these reforms. Using various performance indicators such as asset return, equity return, net interest margin, and profitability index, and these ratios and other bank performance proxies had also been on the negative and falling numbers in several researches. These factors diminished trust in the baking market, and also undermined the confidence of investors. When banks do well, of course, it translates into healthy economic well-being because they will lend to the real sector, thereby solving the macroeconomic problems. The overall effect can be felt by the small to medium production scale. With these reforms in place the benefits relate to bank performance is still a doubt to many people. After the Soludo's bank recapitalization, several other banks had gone down the lane. Such as Oceanic bank, Intercontinental bank, Afri Bank and others. The recent wage of bank downsizing and staff reduction in allowances had being a crucial problem to the Nigerian economy. 
Despite these reforms banks are still not performing satisfactorily within the country. However, using different performance indicators such as return on assets, return on equity, net interest margin, and profitability index. These ratios and others proxies of bank performance had also been on the negative and falling digits in several researches. These factors have reduced performance in the banking sector, while also eroded investors' confidence too. Of course, when banks do well, it translates to a healthy economic wellbeing; because they will lend to the real sector thereby solving the macroeconomic problems; as the overall effect may be felt by the small and medium scale enterprises in the country.

\section{REVIEW OF LITERATURE}

\subsubsection{Theoretical Review}

The theoretical foundation of this research is moored on the relationship that exists between financial intermediation and the financial system. The origin of the Finance and Growth relationship can be traced to the works of Schumpeter (1912) who argued that financial services are paramount in economic growth of the exchange economy. Literatures on the role of financial intermediation and the financial system in economic development were rekindled by Mckinnon (1973) and Shaw (1973). In their clarifications, they opined that functions of financial institutions in the savings-investment process were highlighted as being an effective conduit for the mobilisation and allocation of capital by equilibrating the supply of loanable funds with the demand for investment funds, (banking activities) and the transformation and distribution of risks.

They further add that 'financial liberalization' theory which they argued that government restrictions on the banking system restrain the quality and quantum of investment which is dependent on money supply $\left(\mathrm{M}_{2}\right)$, more so a theoretical relationship between financial policy reforms and money market operations.

Therefore, in the traditional Keynesian theory; the impact of monetary policy can be transmitted to the rest of the economy through the monetary system. Owing to the fact that the banking system provides transaction services and manage the nation's payments system; provides backup liquidity to grease the economy; and they are conduit through which monetary policy is been transmitted. Because of their special function in the economy, the government set up a safety net to protect the banking system from eminent collapse.

\subsubsection{Empirical Review}

Asekome and Abieyuwa (2014) appraised major banking sector reforms in Nigeria from 1958 to 2011, they observed that most of the banking sector reforms in Nigeria were reactive rather being proactive and directed towards particular issues that arose from time to time. They asserted that the approach of regulatory authorities should be holistic because most of the positive impacts of many of the reforms were short lived and unsustainable. They further recommended the need to strengthen and monitor the supervisory capacity of the apex authorities through effective training and capacity building for $\mathrm{CBN}$ and the NDIC to strengthen their effectiveness. They also suggested the need to transfer some of the functions of CBN to other apex agencies such as the NDIC as the CBN appears to be over saddled with many responsibilities beyond its present capacity. Uduak and Udonwa (2015) investigated the performance of Commercial Banks in Nigeria before and after the Banking Sector Reforms from 19702012. The Error Correction Mechanism and Chow test were adopted to model the variables under consideration. The study found out that the reforms brought about changes in Commercial Banks Performance in Nigeria; as the level of profit (measured by NIM) improved above a single digit of 9.17 in 1996 to 16.18 in 2004 and peaked at 20.96 in 2011 . Which translated into a mean profit of 2.40 recorded in the deregulated period as against 1.54 recorded in the regulated period.

Adolphus and Daerego (2013) examined the effects of banking sector reforms on bank management practices in Nigeria. Comparable data for the pre-reform period (1960-1985) and the post-reform period (1986-2008) were captured from the Central Bank of Nigeria (CBN) Statistical Bulletin. These data were analysed with the aid of descriptive and inferential statistical tools. The descriptive statistics indicated steeply rising lending rates and widening bank margins in the post-reform period. Their findings suggested that Critical bank management variables like bank liquidity ratio (BLR) and loan-to-deposit ratio (LTDR) fell outside prudential limits, portraying continuing compliance lapses in the post-reform period. Moreover, the liquidity and funding capabilities of banks did not improve significantly with falling savings rates and cash reserve ratio (CRR). In the pre-reform period, the banks adopted conservative lending policies as the prime lending rate (PLR) became more significant in determining their liquidity and funding profiles. In the post-reform period, bank management were aggressive in their lending policies as the loan-to-deposit ratio was more significantly sensitive to changes in the maximum lending rate (MLR). Both prudential and policy incentives made banks to expand funding to all sectors irrespective of their risk class. Marginal increases in the treasury certificate rate (TCR) and minimum rediscount rate (MRR) brought about a significant reduction in the cash reserve ratio (CRR), hence facilitating banking intermediation.

Umar (2019) appraised banking reforms in Nigeria and its impact on the economy. The findings of this study suggested that in Nigeria, most banks struggle with a low capital base, weak corporate governance, insolvency etc. which necessitated the introduction of the banking sector reform in Nigeria by 2004. However, through banking sector reforms, the government of Nigeria was able to move the economy forward by achieving sustainable economic growth and development. The author is of the opinion that the Nigerian banking sector reforms remained a reference point for the positive development in the Nigeria economy, African region and the world; as the new banking environment created by the reforms has enabled the delisting of Nigeria from the Financial Action Tax Forces (FATF) register of countries that are in breach of the global anti-money laundering and anti-corruption code. Olokoyo, (2013) evaluated the impact of bank reforms on the performance of banks in Nigeria. The author adopted a qualitative research style as data were obtained via questionnaires. However, data obtained were analysed using the Analysis of Variance (ANOVA) method. The findings suggested that the recapitalization and consolidation process had a significant effect on the manufacturing sector of the economy and thus on the Nigerian economy at large. However findings further 
revealed that despite the reforms, post consolidation challenges like challenges of increased return on investment still existed. Gidigbi (2017) assessed the impact of banking reforms on banks' performance and economic growth for the period 1981 to 2015; the ANOVA model was fit into a Stepwise Regression. Using dummy variables to isolate reform periods. The results showed that banking reforms contributed positively to economic growth, especially for the period 1999 to 2004. Furthermore, it was observed that banking reforms contributed negatively to banks' performance, following the 1993 reforms. The study confirmed that banking system reforms in Nigeria have dual impact on the economy and banks' performance. Thus, the study recommended that pre-crisis reforms testing by the apex bank be carried out frequently. Ifeanyi and Emmanuel (2017) examined the effect of banking reforms on economic development of Nigeria for the period 1986 - 2014. Data for the study were sourced from Central Bank of Nigeria Statistical Bulletins, publications of National Bureau of Statistics and Annual Reports of Deposit Money Banks. The Ordinary Least Square (OLS) regression was employed for the analysis. The study revealed that the Minimum Capital Base of banks has a positive and significant effect on Gross Domestic Product; while banks' minimum capital base has a negative and significant effect on Inflation. However, it was observed that banks' minimum capital base has a significant positive effect on unemployment. Thus, the study amongst others concluded that the monetary authorities should always take Minimum Capital Base of banks into consideration in banking reforms as it has the capacity to trigger economic development of Nigeria.

Umor and Austin (2014) accessed banking reforms from a financial management standpoint. Financial data drawn from CBN covering 23 years (1985-2008) were analysed using the OLS model. The study examined bank capital as a predictor variable in relation to aggregate private sector credit and gross domestic product as respective criterion variables. The findings established efficacy of bank capital as significant determinant of the dynamics of aggregate private sector credit and gross domestic product in Nigeria. Ikpefan, and Kazeem (2013) investigated the effectiveness of economic policy reforms in the Nigerian banking industry from 2000 to 2009; to detect whether bank mergers produced any performance gains in the banking industry. The panel data OLS was employed to investigate if any significant effect on the performance of banks from the pre to the post-merger periods exist. The results of the study suggests that merger created synergy is statistically significant with an increasing post-merger financial performance.

Tomola and Sola (2011) examined the implications of financial reform and interest rate behaviour on economic growth in Nigeria. The co integration and error correction model were used on time series data from 1970-2006. The results demonstrated that financial reform and interest rates have significant impact on economic growth in Nigeria. However, the authors recommended that government embark on growth enhancing financial reform and be sensitive to the behaviour of interest rates for overall economic growth in the country. Nathanael (2014) investigated the impact of the banking sector reforms on the Nigerian economy using the Ordinary Least Squares (OLS) technique in assessing the data on variables from 1980 to 2012 . The result showed that the minimum capital base which is at the heart of the banking sector reform has a positive and significant relationship with the level of economic growth. While high interest rate policy has been detrimental to the level of economic progress in Nigeria. The result further revealed that the expansionary monetary policy has been crucial and critical in the development process in Nigeria. They recommended amongst others that the monetary authorities should further increase the minimum capital base and there should be perpetuation of the expansionary monetary policy.

Pavtar and Agir (2016) investigated the nexus between money market and economic growth in Nigeria, using data from 1985-2014. The OLS method was adopted to analyse the data. The study found that Treasury bill, Treasury certificate, Commercial paper do not have any significant effect on the gross domestic product (GDP) of Nigeria while Certificate of deposits was found to significantly impact on the gross domestic product (GDP) of Nigeria. The study recommended amongst others the need for Government to create appropriate macroeconomic policies, legal framework and consolidate on existing reforms to improve and deepening the market; so as to spur economic growth.

\subsubsection{Conceptual Framework Money Market instruments}

The money market was developed with two main objectives in mind: to provide the public and private sectors with means to raise short-term money and invest cash and to serve as a conduit for the management of liquidity and money by the monetary authorities. One is therefore not surprised that the money market did not come into existence until the establishment of the CBN in 1959. The major nine institutions operating in the money market are the Treasury/Central Bank dealing in treasury bills, treasury certificates, government development stocks, (all Federal government borrowing instruments), the commercial banks, dealing mainly in bankers acceptances, certificates of deposits, and bankers unit funds and private companies dealing mainly in commercial papers.

Economists have come to disagree on the level of government intervention in economic and financial activities all over the world. While some believe that many regulations are necessary in order to protect the depositors' funds and confidence, others believe that banks are overregulated (Adam, 2005; Elumilade, 2010). For instance, the economic theory of regulation postulates that regulation result from the desire of government to eliminate or correct market failure. It seems that economic theory of regulation has gained more acceptance among economists as Llewellyn (1986) puts it. Regulation is necessary in the case of banks specifically to maintain safe and sound banking system that can meet its obligation without difficulty. Hence, a high solvency and liquidity level is expected of individual banks than they would ordinarily maintain.

Loss of public confidence in the banking system occurs when a bank or some banks in the system experience illiquidity or insolvency resulting in a situation where depositors fear the loss of their deposits and a consequent break down of contractual obligations that results in runs on the bank. While a bank is said to be illiquid when it could no longer meet its liabilities as they mature for payment, it is said to be insolvent when the value of its realizable assets is less than the total value of its liabilities (a case of "negative net worth"). The above is inconsistent with the work Lagunju (2014) that found significant relationship between 
liquidity and commercial banks profitability, but he further adds that the success of deposit money bank is its ability to manage liquidity because excess liquidity and illiquidity are "Financial disease". The uncertainty generated as a result of loss of confidence in banking institutions, if left unchecked, often raises real interest rates, creates higher costs of transactions and disrupts the payment mechanism with the attendant economic consequence (Okafor, 2012).

Chuke (2004) opines that the money market is one that creates opportunities for raising and investing short term funds. $\mathrm{He}$ further adds that short term funds are funds which are lent or borrowed for a period which might ranges from as short as overnight up to about one year and sometimes longer. Various financial instruments are exchanged in the money market. The money market instruments include Treasury bills, Treasury certificates, bill of exchange, commercial papers, certificate of deposit, and bankers' acceptance.

\section{Methodology}

The study utilized annual time series data for the period 2004-2018, obtained from Central Bank of Nigeria (CBN) statistical bulletin. The data used includes; commercial paper, total deposits, broad money supply and credit to the private sector. The model adopted for this study is thus specified below as;

$C P_{i, t}=\beta_{o}+\beta_{1} T D+\beta_{2} M 2+\beta_{3} C P S+\varepsilon_{i, t}$

(1)

Where;

CP refers to Credit to the Private Sector

TD is Total Deposits in the banking system

M2 refers to Treasury certificates

CPS refers to Commercial deposit

\section{RESULTS AND DISCUSSION OF FINDINGS}

\subsubsection{Descriptive Statistics of Data}

The analysis of descriptive statistics is hereby performed so as to find out the properties of the data. Table 1 shows the data characteristics including total number of observations, means, standard deviation, Jarque-Bera statistics and their respective minimum and maximum values of the respective variables from the period of 2004 to 2018 .

Table 1: Descriptive Statistics

$\begin{array}{lllll} & \text { CP } & \text { CPS } & \text { M2 } & \text { TD } \\ \text { Mean } & 173.6333 & 16.42267 & 12480.08 & 51927.71 \\ \text { Median } & 80.10000 & 18.60000 & 12172.49 & 3296.230 \\ \text { Maximum } & 822.7000 & 20.77000 & 25079.72 & 308851.8 \\ \text { Minimum } & 1.100000 & 7.990000 & 2131.820 & 19.72000 \\ \text { Std. Dev. } & 235.4932 & 4.873503 & 7391.454 & 88600.67 \\ \text { Skewness } & 1.612862 & -0.952921 & 0.144893 & 1.945479 \\ \text { Kurtosis } & 4.902697 & 2.192443 & 1.878764 & 5.879706 \\ & & & & \\ \text { Jarque-Bera } & 8.765966 & 2.677740 & 0.838217 & 14.64516 \\ \text { Probability } & 0.012488 & 0.262142 & 0.657633 & 0.000660 \\ & & & & \\ \text { Sum } & 2604.500 & 246.3400 & 187201.2 & 778915.7 \\ \text { Sum Sq. Dev. } & 776398.7 & 332.5145 & 7.65 \mathrm{E}+08 & 1.10 \mathrm{E}+11 \\ \text { Observations } & 15 & & & 15\end{array}$

From table 1 above, it was observed that the mean values of commercial paper (CP), credit to the private sector (CPS), money supply (M2) and total deposit (TD) were 173.6333, $16.42267,12480.08$ and 51927.71 respectively. The variability in the distributions as captured by the standard deviation, suggests that $\mathrm{CP}$ and $\mathrm{TD}$ where dispersed from their mean since its standard deviation value where above their mean value. Conversely, CPS and M2 were found not to be very volatile.

Furthermore, the skewness values of CP (1.612862), M2 (0.144893) and TD (1.945479) suggests that are positively skewed. Contrariwise, only CPS (0.952921) was negatively skewed. Finally, the Jarque-Bera statistics indicates that TD and $\mathrm{CP}$ were considered not to have a normal distribution since their p-values were less than $10 \%$ level. However, only CPS and M2 where considered normally distributed.

\subsubsection{Correlation Analysis}

Correlation is a statistical tool that describes the degree of linear association between two or more variables. From Table 2, a weak and negative association was noticed amongst the variables. However, only the association between CP and M2 was found to be significant at $5 \%$.

Furthermore, according to Gujarati (2006) if the pair-wise correlation among the independent variables is greater than $80 \%$, then multicollinearity is said to have occurred. From table 2 below, the result attested to the fact that pair-wise correlation for all variables are less than $80 \%$. The highest percentage of pair-wise correlation was $-50.73 \%$ between commercial paper (CP) and money supply (M2). Therefore, it can be concluded that multicollinearity does not exist in the model. 
Table 2: Pearson Correlation Matrix

\begin{tabular}{l|llll}
\hline \hline $\begin{array}{l}\text { Correlation } \\
\text { Probability }\end{array}$ & CP & CPS & M2 & TD \\
\hline CP & $\begin{array}{l}\text { 1.000000 } \\
----\end{array}$ & & \\
& & & \\
CPS & -0.126500 & 1.000000 & & \\
& $(0.6533)$ & ---- & & \\
M2 & -0.507365 & 0.765924 & 1.000000 & \\
& $\left(0.0535^{\mathrm{b}}\right)$ & $\left(0.0009^{\mathrm{a}}\right)$ & ---- & \\
& & & \\
$\mathrm{TD}$ & -0.367054 & 0.153888 & 0.666040 & 1.000000 \\
& $(0.1784)$ & $(0.5840)$ & $\left(0.0067^{\mathrm{a}}\right)$ & ---- \\
\hline \hline
\end{tabular}

p-values are in parenthesis ( )

$\mathrm{a} / \mathrm{b} / \mathrm{c}$, indicates significance at $1 \%, 5 \% \& 10 \%$ respectively

Source: Authors Computation Using Eviews 10+

\subsubsection{Unit Root Test}

Stationarity implies that the mean, variance and covariance are constant across different periods. Existence of unit roots can lead to serious issues such as; spurious regressions and errant behaviour variables due to econometric assumptions for analysis not being valid. This study tested for the stationarity of all variables used by applying two different time-series unit root test namely; the Augmented Dickey Fuller (ADF) and Philps Perron (PP) tests. According to table 3 below, all variables were levels stationary; i.e. I(0).

Table 3 Unit Root Test Results

\begin{tabular}{lcccl}
\hline Variables & ADF Test & Remarks & PP Test & Remarks \\
CP & $-5.094867^{\mathrm{a}}$ & $\mathrm{I}(0)$ & $-5.112462^{\mathrm{a}}$ & $\mathrm{I}(0)$ \\
\hline CPS & $-3.633633^{\mathrm{b}}$ & $\mathrm{I}(0)$ & $-3.243441^{\mathrm{b}}$ & $\mathrm{I}(0)$ \\
\hline M2 & $-4.264593^{\mathrm{a}}$ & $\mathrm{I}(0)$ & $-4.351742^{\mathrm{a}}$ & $\mathrm{I}(0)$ \\
\hline TD & $-4.347729^{\mathrm{a}}$ & $\mathrm{I}(0)$ & $-4.346211^{\mathrm{a}}$ & $\mathrm{I}(0)$ \\
\hline
\end{tabular}

$\mathrm{a} / \mathrm{b} / \mathrm{c}$, indicates significance at $1 \%, 5 \% \& 10 \%$ respectively.

Source: Author's Computation Using Eviews 10+

\subsubsection{Estimated Result of Banking Sector Reform and Money Market Performance in Nigeria}

From Table 4, our findings suggest that the estimated results from equation (1) indicated that credit to the private sector (CPS) and total deposits (TD) has a positive and significant effect on commercial paper (CP) in Nigeria at $1 \%$ and $10 \%$ significance level respectively. The positive relationship observed amongst the explanatory variables on the dependent variable $(\mathrm{CP})$ suggests that an increase in CPS and TD will lead to a rise in the volume of commercial paper (CP) traded on the Nigerian Stock Exchange.

However, money supply (M2) was found to have a negative and significant relationship with $\mathrm{CP}$ at $1 \%$ level. This suggests that an increase in a rise in the total money supply in the economy will lead to a fall in the volume of commercial paper (CP) traded on the Nigerian Stock Exchange.

\section{Table 4: Summary of the effect of Banking Sector Reform and Money Market Performance in Nigeria}

Dependent Variable: CP

Method: Least Squares

Date: 02/04/20 Time: 13:56

Sample: 20042018

Included observations: 15

\begin{tabular}{lllll}
\hline \hline Variable & Coefficient & Std. Error & t-Statistic & Prob. \\
\hline \hline $\mathrm{C}$ & -167.1946 & 208.5936 & -0.801532 & 0.4398
\end{tabular}




\begin{tabular}{lllll} 
CPS & 63.49963 & 21.96638 & 2.890765 & $0.0147^{\mathrm{a}}$ \\
M2 & -0.064976 & 0.019186 & -3.386726 & $0.0061^{\mathrm{a}}$ \\
TD & 0.002097 & 0.001041 & 2.013782 & $0.0692^{\mathrm{c}}$ \\
\hline \hline R-squared & 0.578870 & Mean dependent var & 173.6333 \\
Adjusted R-squared & 0.464016 & S.D. dependent var & 235.4932 \\
S.E. of regression & 172.4067 & Akaike info criterion & 13.36077 \\
Sum squared resid & 326964.8 & Schwarz criterion & 13.54958 \\
Log likelihood & -96.20576 & Hannan-Quinn criter. & 13.35876 \\
F-statistic & 5.040067 & Durbin-Watson stat & 1.942945 \\
Prob(F-statistic) & 0.019445 & & \\
\hline \hline
\end{tabular}

$\mathrm{a} / \mathrm{b} / \mathrm{c}$, indicates significance at $1 \%, 5 \%$ \& $10 \%$ respectively

Source: Authors Computation Using Eviews 10+

Furthermore, the adjusted $\mathrm{R}^{2}$ value suggests that $57.87 \%$ of the variation in the dependent variable; $\mathrm{CP}$ is explained by the independent variables (CPS, M2 and TD). The $42.13 \%$ variance in $\mathrm{CP}$ is explained by other factors not captured in this research. Also, the F-statistic of 5.040067 suggests that the model is significant at a $1 \%$ level. Finally, Durbin-Watson statistic of 1.942945 indicates absence of positive autocorrelation in the model.

\section{CONCLUSION AND RECOMMENDATIONS}

This study had set forth to provide an insightful understanding as to the relationship between banking sector reform and money market performance in Nigeria. The study utilized time series data spanning $2004-2018$. The various unit root tests suggested that all variables where levels stationary.

The findings of the study indicated that an increase in the credit to the private sector (CPS) and total deposits (TD) will lead to a significant rise in the volume of commercial paper (CP) traded on the Nigerian Stock Exchange. While an increase in a rise in the total money supply in the economy will lead to a significant fall in the volume of commercial paper (CP) traded on the Nigerian Stock Exchange.

This study therefore recommends that;

1. That the government continue to consolidate on existing reforms to improve deepening of the money market.

2. A continued expansion of the monetary policy within the economy is necessary to boosting growth in the money market.

\section{REFERENCES}

[1] Agbahiwe, P. U. (2014). nigerian banking reforms in strategic financial management perspective: least square specific. European Journal of Accounting Auditing and Finance Research , 3, No.3,(3), 40-53.

[2] Aliyu, U. L. (n.d.). Banking Reforms in Nigeria and Its Impact on the Economy. International Journal of Economics \& Business , 3, Issue (1), 4955.

[3] Asekome, M. O. (2014 ). Challenges of Banking Sector Reforms in Nigeria: An Appraisa. International Journal of Business and Social Science, 5(7).
[4] Gidigbi, M. O. (2017). An Assessment of the Impact of Banking Reforms on Economic Growth and Bank Performance in Nigeria. CBN Journal of Applied Statistics., 8(2), 143-162.

[5] Ikpefan, O. A. (2013). The Effect of Merger on Deposit Money Banks Performance in the Nigerian Banking Industry. Journal of Applied Finance \& Banking, (print version),1792-6599 (online) Scienpress Ltd, 2013, 3(4), 105-123.

[6] ISU, K. C. (2013). The Impact of Capitalization on Bank Performance in Nigeria 1970 - 2010: An Assessment. international review of management and business, 2(3).

[7] Kenn-Ndubuisi, J. I. (2015). effects of recapitalisation on commercial banks survival in nigeria: pre and post camel anaylsis. European Journal of Accounting, Auditing and Finance Research, 3(9), 12-30.

[8] Mohammed Alhaji Audu, M. G. (2015, may). The Impact of Banking Sector Reforms on the Performance of Commercial Banks in Nigeria. Journal of Business and Management (IOSR-JBM) www.iosrjournals.org, 17(5), 11-16. doi:DOI: 10.9790/487X-17541116

[9] Nathanael O. Eriemo, P. (2014). Banking Sector Reforms and Critical Factors in Nigeria's Economic Growth Process. Journal of Economics and Sustainable Development, 5 (17).

[10] Olorunfemi2, T. M. (2011). Financial reforms, interest rate behaviour and economic growth in Nigeria. Journal of Applied Finance \& Banking., 1(4), $39-55$.

[11] Pavtar, A. (2016). The Nexus between Money Market Instruments and Nigeria's Economic Growth: A Time Series Analysis. Journal of Accounting and Financial Management www.iiardpub.org, 2 (3).

[12] Thompson, A. J. (2013). Modeling the Effects of Banking Sector Reforms on Bank Management Practices in Nigeria. Journal of Emerging Issues in Economics, Finance and Banking (JEIEFB), Volume:2 (6).

[13] Uduak M. Ekong, U. E. (2015, may 15). Banking Sector Reforms and the Performance of Commercial Banks in Nigeria. Journal of World Economic Research (http://www.sciencepublishinggroup.com/j/jwer), 4(3), 45-60. doi: doi: 10.11648/j.jwer.20150403.

\section{AUTHORS}

First Author - Krokeme Okoyan, Doctoral Student Banking \& Finance Niger Delta University, Wilberforce island Amassoma Bayelsa State., Kemelight80@gmail.com

Second Author - Peter Ayunku, Faculty of Management Science Niger Delta University, Wilberforce island Amassoma Bayelsa State, peterayunku@yahoo.com 
